\title{
KEMATANGAN KARIR MAHASISWA BK STKIP PGRI SUMBAR DAN PENERAPANNNYA DALAM LAYANAN KONSELING KARIR (STUDI TERHADAP MAHASISWA BK ANGKATAN 2018)
}

\author{
Nada Ahrama ${ }^{1}$, Yasrial Chandra ${ }^{2}$, Besti Nora Dwi Putri ${ }^{3}$ \\ Prodi Bimbingan Konseling STKIP PGRI Sumatera Barat \\ Email: nadaahrama0913@gmail.com
}

\begin{abstract}
This research is motivated by students of STKIP PGRI West Sumatra Counseling Guidance in their career maturity. The purpose of this study was to describe 1) Career maturity of Guidance Counseling students seen from their involvement in career planning activities. 2) The career maturity of Counseling Guidance students is seen from the desire to explore and obtain career information. 3) The career maturity of Counseling Guidance students is seen from the knowledge of making adequate decisions. 4) The career maturity of Counseling Guidance students is seen from the knowledge of some job information and the world of work. 5) The career maturity of Guidance Counseling students is seen from exploring the preferred job. 6) The career maturity of Counseling Guidance students is seen from the reality in making career decisions. This research was conducted using a quantitative descriptive method. The research population was 87 Guidance Counseling students class 2018, while the sampling of this study used a total sampling technique. The instrument used is a questionnaire. Analysis of the data used is interval data. Based on the results of research that has been carried out on each indicator classified as high criteria. Based on the results of the study, it can be recommended to Guidance Counseling students in order to maintain their career maturity.
\end{abstract}

Keyword: Career Maturity, Student Guidance Counseling

\section{ABSTRAK}

Penelitian ini dilatarbelakangi mahasiswa Bimbingan Konseling STKIP PGRI Sumbar dalam kematangan karirnya. Tujuan Penelitian ini adalah untuk mendeskripsikan 1) Kematangan karir pada mahasiswa Bimbingan Konseling dilihat keterlibatannya dalam aktifitas-aktivitas rencana karir. 2) Kematangan karir mahasiswa Bimbingan Konseling dilihat dari adanya keinginan untuk menggali dan mendapatkan informasi karir. 3) Kematangan karir mahasiswa Bimbingan Konseling dilihat dari pengetahuan tentang membuat keputusan yang memadai. 4) Kematangan karir mahasiswa Bimbingan Konseling dilihat dari pengetahuan tentang beberapa informasi pekerjaan dan dunia kerja. 5) Kematangan karir mahasiswa Bimbingan Konseling dilihat dari mendalami pekerjaan yang lebih disukai. 6) Kematangan karir mahasiswa Bimbingan Konseling dilihat dari realitas dalam membuat keputusan karir. Penelitian ini dilakukan dengan menggunakan metode deskriptif kuantitatif. Populasi penelitian yaitu sebanyak 87 orang mahasiswa Bimbingan Konseling angkatan 2018, sedangkan pengambilan sampel penelitian ini menggunakan teknik total sampling. Istrumen yang digunakan adalah angket. Analisis data yang digunakan adalah data interval. Berdasarkan hasil penelitian yang telah dilakukan pada setiap indikator tergolong dalam kriteria tinggi. Berdasarkan hasil penelitian dapat direkomendasikan kepada mahasiswa Bimbingan Konseling agar dapat mempertahankan kematangan karir yang dimiliki.

Kata Kunci: Kematangan Karir, Mahasiswa Bimbingan Konseling 


\section{PENDAHULUAN}

Mahasiswa adalah seorang individu yang sedang dalam proses menempuh pendidikan di perguruan tinggi yang mana terdiri dari akademik, politeknik, sekolah tinggi, institut dan universitas. Mahasiswa berada dalam lingkungan perguruan tinggi tidak terlepas dari proses kegiatan belajar. Proses kegiatan belajar menekankan mahasiswa untuk mampu menyelesaikan tugas perkembangannya. Esensi belajar merupakan suatu aktivitas berproses yang dalamnya terjadi perwujudanperwujudan perilaku dengan keterikatan satu sama lain. Usia mahasiswa tergolong dalam tahapan usia rentangan remaja akhir. Mahasiswa dikategorikan pada tahap perkembangan yang rentangan usianya 18 sampai 25 tahun, yang masuk dalam kategori pada masa remaja akhir sampai masa dewasa awal dan dilihat dari segi perkembangan, tugas perkembangan yang dilakukan pada usia ini yaitu pemantapan pendirian hidup.

Menurut Hurlock

(2002:152)

menyampaikan salah satu tugas perkembangan remaja dan menjadi tugas perkembangan untuk mahasiswa, yaitu mempersiapkan karir serta kemandirian pada bidang ekonomi. Adanya tugas perkembangan ini disebabkan oleh seorang mahasiswa sudah mempunyai fisik dan kognitif yang matang sehingga telah mampu memasuki lapangan pekerjaan. Dengan demikian, mahasiswa dituntut memiliki kesiapan diri untuk memasuki dunia kerja sehingga pada saat usia dewasa sudah memiliki kemandirian baik secara karir maupun ekonomi.

Memilih pekerjaan dan mempersiapkan diri untuk bekerja merupakan salah satu tugas masa remaja pada perkembanganya (Hurlock, 2002:209). Orientasi masa depan remaja pada dasarnya adalah pekerjaan ataupun karir, untuk memasuki dunia karir sangat dibutuhkan pendidikan. Pendidikan di pandang sebagai langkah awal untuk mendapatkan penguasaan pengetahuan dan keterampilan dalam pencapaian karir yang selama ini dicita-citakan menurut Nurmi (Desmita, 2009:203). Besarnya minat seseorang pada pendidikan sangat dipengaruhi oleh minat pada pilihan pekerjaan (Hurlock, 2002: 220). Sekolah selain berfungsi pengajaran (mencerdaskan) juga berfungsi pendidikan (transportasi norma). Keterkaitanya dengan fungsi pendidikan, sekolah dirancang untuk melatih remaja secara intelektual, mampu menanamkan kesiapan kerja dan memiliki keterampilan sosial.

Seorang mahasiswa pada tahap perkembangannya berada pada tahap eksplorasi yang mana berada pada tahap perkembangan karir. Tahap eksplorasi merupakan tahap yang dimiliki mahasiswa yang sudah mampu mengidentifikasikan minat, keterampilan dalam rangka kesesuaian antara dirinya dan pekerjaan (Winkel dan Hastuti, 2006:32). Pada tahap eksplorasi ini, mahasiswa melakukan pencarian tentang pilihan karir yang sesuai dengan dirinya, yaitu mulai membuat perencanaan terhadap masa depan dengan menggunakan kesiapan diri sendiri, untuk mengenali minat serta kemampuan yang dimiliki. Kematangan karir tersebut ditandai oleh enam hal, yaitu: (1) keterlibatan dalam aktivitas-aktivitas rencana karir; (2) adanya keinginan untuk menggali dan mendapatkan informasi karir; (3) memiliki pengetahuan tentang membuat keputusan yang memadai; (4) memiliki pengetahuan tentang beberapa informasi pekerjaan dan dunia kerja; (5) mendalami pekerjaan yang lebih disukai; dan (6) realistis dalam membuat keputusan karir. Sehingga kehadiran program konseling karir di perguruan tinggi tidak dapat dibantah. Beragam kebutuhan untuk memenuhi mencapai perkembangan karir, terutama orientasi karir dan strategi nyata mengatasi permasalahan karir mahasiswa semakin jelas urgensinya.

Crites (Salami, 2008:84) bahwa kematangan karir sebagai suatu tingkat 
kemampuan individu dalam komponenkomponen pengetahuan dan sikap yang tepat sesuai dengan ketetapan perkembangan karir yang dimiliki seorang individu. Menurut Savickas (Tekke \& Ghani, 2013:75), tahapan kematangan karir di tentukan dari bagaimana kesiapan seorang individu memiliki sumber informasi serta menciptakan keputusan karir yang sesuai dengan tingkatan usianya untuk dapat mengatasi adanya tugas perkembangan yang sesuai dengan dirinya. Sementara menurut Super (Winkel dan Hastuti, 2006:90), keberhasilan seorang individu untuk menyelesaikan tugas perkembangan karir yang sesuai dalam tahapan proses karirnya yaitu individu yang sudah mencapai adanya kematangan karir.

Melatar belakangi adanya hubungan antara ilmu yang dipelajari dengan pekerjaan yang ditekuni oleh lulusan perguruan tinggi, sehingga diharapkan para mahasiswa sudah menjalani proses kematangan karir. Super (Winkel dan Hastuti, 2006:52) membagi tahapan perkembangan karir menjadi lima tahap, yaitu fase growth (pengembangan) dari saat lahir sampai umur lebih kurang 15 tahun, fase exploration (eksplorasi) dari umur 15 sampai 24 tahun, fase establishment (pemantapan) dari umur 25 sampai umur 44 tahun, fase maintenance (pembinaan) dari umur 45 sampai 64 tahun, dan fase decline (kemunduran) dari masa pensiun hingga akhir hayat. Berkaitan pentingnya pembahasan terhadap masalah kematangan karir ini, permasalahan kematangan karir pada mahasiswa harus ditekankan pada kompetensi, tujuan karir, menciptakan adanya perkembangan karir yang mandiri, perencanaan yang matang, motivasi serta efikasi pada diri mahasiswa. Dari penelitian yang dilakukan oleh Hami, dkk yang berjudul Gambaran Kematangan Karir Pada Para Calon Sarjana dilingkungan Fakultas Psikologi Universitas Padjadjaran pada 2006. Menunjukan bahwa terdapat $52,8 \%$ para mahasiswa berada dalam kategori belum adanya kesiapan karir. Hal tersebut menyebutkan bahwa sebagian besar dari mahasiswa secara umum berada masih berada dalam tingkatan belum siap untuk menentukan arah karirnya dengan berdasarkan kemampuan untuk melakukan eksplorasi karir, membuat perencanaan karir serta mengambil keputusan dan juga wawasannya mengenai bagaimana dunia kerja nantinya.

Dari penjelasan diatas maka dapat peneliti simpulkan bahwa mahasiswa berada dalam lingkungan perguruan tinggi tidak terlepas dari proses kegiatan belajar. Mempersiapkan karir serta kemandirian pada bidang ekonomi. Adanya tugas perkembangan ini disebabkan oleh seorang mahasiswa sudah mempunyai fisik dan kognitif yang matang sehingga telah mampu memasuki lapangan pekerjaan. Dengan demikian,mahasiswa dituntut memiliki kesiapan diri untuk memasuki dunia kerja sehingga pada saat usia dewasa sudah memiliki kemandirian baik secara karir maupun ekonomi. Kemandirian tersebut didukung dengan kematangan karir yang dimiliki mahasiswa tersebut dimana kematangan karir merupakan suatu bentuk kemampuan individu dalam komponenkomponen pengetahuan dan sikap yang tepat sesuai dengan ketetapan perkembangan karir yang dimiliki seorang individu tersebut.

\section{METODE PENELITIAN}

Berdasarkan batasan masalah dan tujuan penelitian yang telah dikemukakan, maka jenis dari penelitian ini yaitu penelitian deskriptif. Dimana penelitian deskriptif mendeskripsikan gejala-gejala, aktifitas yang ada dalam suatu kelompok yang sebagai mana adanya. Menurut Andih (2018:78) penelitian deskriptif kuantitatif yaitu menggambarkan sesuatu secara langsung saat melakukan penelitian dan memeriksa gejala tertentu serta sebab-sebab saat melakukan penelitian tersebut. Sedangkan menurut Zellatifanny \& 
Mudjiyanto (2018:84) ada beberapa tujuan penelitian deskriptif : deskripsi tentang ciri-ciri atau gejala yang berhubungan dengan populasi tertentu, perkiraan tentang proporsi populasi yang memiliki ciri-ciri tersebut. Berdasarkan teori tersebut peneliti akan mendeskripsikan tentang bagaimana kematangan karir mahasiswa BK STKIP PGRI Sumbar dan penerapannya dalam layanan konseling karir (studi terhadap mahasiswa BK angkatan 2018).

\section{HASIL DAN PEMBAHASAN}

Berdasarkan hasil penelitian ditemukan bahwa Kematangan Karir Mahasiswa BK STKIP PGRI Sumbar dan Penerapannya Dalam Konseling Karir studi terhadap mahasiswa BK angkatan 2018 tergolong kedalam kriteria sangat rendah $0 \%$, kriteria rendah $0 \%$, kriteria cukup tinggi 51,72\%, kriteria tinggi $42,53 \%$, sangat tinggi $5,75 \%$. Jadi dapat bahwa Kematangan Karir Mahasiswa BK STKIP PGRI Sumbar dan Penerapannya Dalam Konseling Karir studi terhadap mahasiswa BK angkatan 2018 disimpulkan tergolong dalam cukup tinggi. Selanjutnya akan dibahas secara khusus:

\section{a. Keterlibatan dalam Aktivitas-aktivitas Rencana Karir}

Berdasarkan hasil penelitian menunjukan bahwa mahasiswa BK 2018 dengan presentase $44,83 \%$ yang memiliki keterlibatan dalam aktivitas-aktivitas rencana karir yang tinggi. Artinya sebagian besar mahasiswa memiliki keterlibatan dalam aktivitas-aktivitas rencana karirnya. Dilihat dari indikator tersebut mahasiswa BK membuat catatan tentang rencana pekerjaan nantinya. Mahasiswa BK mengikuti berbagai seminar mengenai karir. Melibatkan diri dalam aktivitas-aktivitas yang diadakan dikampus. Belajar kerjasama agar terbiasa saat sudah terlibat dalam dunia kerja.

Menurut

Simamora

(2001:100) perencanaan karir adalah suatu proses dimana individu dapat mengidentifikasi dan mengambil langkah-langkah untuk mencapai tujuan karirnya. Perencanaan karir melibatkan pengidentifikasian tujuan-tujuan yang berkaitan dengan karir dan penyusunan rencana-rencana untuk mencapai tujuan tersebut. Perencanaan karir merupakan proses untuk: a. Menyadari diri sendiri terhadap peluang-peluang, kesempatan-kesempatan, kendala-kendala, pilihan-pilihan, dan konsekuensi-konsekuensi; b. Mengidentifikasi tujuan-tujuan yang berkaitan dengan karir; c. Penyusunan program kerja, pendidikan, dan yang berhubungan dengan pengalamanpengalaman yang bersifat pengembangan guna menyediakan arah, waktu, dan urutan langkahlangkah yang diambil untuk meraih tujuan karir.

Berdasarkan penjelasan tersebut keterlibatan dalam aktivitas-aktivitas rencana karir mahasiswa BK sudah dapat dilakukan dengan berbagai kegiatan yang bisa dilakukan dimana kegiatan tersebut dapat melibatkan diri dalam aktivitas-aktivitas rencana karir bagi mahasiswa BK untukmeraih tujuan karir.

\section{b. Adanya Keinginan Untuk Menggali dan Mendapatkan Informasi Karir}

Berdasarkan hasil penelitian bahwa mahasiswa BK 2018 dengan persentase $44,83 \%$ yang memiliki adanya keinginan untuk menggali dan mendapatkan informasi karir yang tinggi. Artinya sebagian besar mahasiswa BK sudah adanya keinginan untuk menggali dan mendapatkan informasi karir. Dari indikator tersebut dapat dilihat bahwa mahasiswa BK berusaha mencari informasi pekerjaan yang diminati dengan bertanya dengan orang lain seperti kepada orang tua, orang yang terlibat dalam bidang pekerjaan yang diminati. berusaha menggali informasi karir yang diminati melalui media cetak dan media elektronik

Menurut Suherman (2010: 117) indikator-indikator eksplorasi karir antara 
lain berusaha menggali dan mencari informasi karir dari berbagai sumber (guru bimbingan dan konseling, orang tua, orang yang sukses), memiliki pengetahuan tentang potensi diri (bakat, minat, intelegensi, kepribadian, nilainilai, dan prestasi), dan memiliki cukup banyak informasi karir. Indikator-indikator tersebut merupakan petunjuk terhadap kriteria bagi individu yang mampu melakukan eksplorasi karir secara efektif, positif dan dinamis. Fungsi dari eksplorasi karir yaitu untuk mengetahui minat, bakat, kemampuan, kelebihan dan kekurangan, dan untuk merencanakan aktivitas-aktivitas yang mendukung karir individu agar mampu mempertimbangkan perencanaan karir sesuai dengan kebutuhan yang terkait dengan karir yang akan dipilih dimasa depan.

Berdasarkan penjelasan tersebut keinginan untuk menggali dan mendapatkan informasi karir mahasiswa BK sudah dapat mencari dan mendapatkan informasi karir diberbagai hal bisa melalui orang tua, orang-oraang yang terlibat dalam bidang pekerjaan tertentu serta dapat pulak mendapatkan informasi tersebut melalui media yang ada seperti media cetak dan media elektronik.

\section{c. Memiliki Pengetahuan tentang Membuat Keputusan yang Memadai}

Berdasarkan hasil penelitian menunjukan bahwa mahasiswa BK 2018 dengan presentase $43,68 \%$ yang memiliki pengetahuan tentang membuat keputusan yang memadai berkategori tinggi. Artinya sebagian besar mahasiswa BK sudah memiliki pengetahuan tentang membuat keputusan yang memadai. Dari indikator tersebut dapat dilihat mahasiswa BK dalam mengambil keputusan memadai memikirkan terlebih dahulu konsekuensi disetiap keputusan yang akan diambil. Bertanggung jawab atas keputusan yang diambil. Optimis jika nanti keputusan yang diambil akan berpengaruh terhadap kehidupan sehari-hari.
Menurut

Eisenfuhr (Lunenburg, 2010:10) pengambilan keputusan adalah proses membuat pilihan dari sejumlah alternative untuk mencapai hasil yang diinginkan. Definisi ini memiliki tiga kunci elemen. Pertama, pengambilan keputusan melibatkan membuat keputusan dari sebuah pilihan. Kedua, pengambilan keputusan adalah proses yang melibatkan lebih dari sekedar pilihan akhir dari antara alternatif. Ketiga, hasil yang diinginkan yang disebut dalam definisi melibatkan tujuan atau target yang dihasilkan dari aktifitas mental bahwa pembuat keputusan terlibat dalam mencapai keputusan akhir.

Berdasarkan penjelasan

tersebut memiliki pengetahuan tentang membuat keputusan yang memadai dapat terlihat dari memikirkan terlebih dahulu konsekuensi disetiap keputusan yang akan diambil, bertanggung jawab atas keputusan yang akan dan telah diambil serta optimis jika keputusan yang diambil tersebut akan berpengaruh terhadap kehidupan sehari-hari.

\section{d. Memiliki Pengetahuan tentang Beberapa} Informasi Pekerjaan dan Dunia Kerja

Berdasarkan hasil penelitian menunjukan bahwa mahasiswa BK 2018 dengan presentase $47,13 \%$ dengan kategori tinggi dalam memiliki pengetahuan tentang beberapa informasi pekerjaan dan dunia kerja. Artinya sebagian besar mahasiswa BK memiliki pengetahuan tentang pekerjaan dan dunia kerja. Dari indikator tersebut dilihat bahwa mahasiswa BK sudah memiliki pengetahuan mengenai pekerjaan dan dunia kerja bagaimana nantinya. Dengan berpikir bahwa dalam dunia kerja membutuhkan orang yang jujur dan kompeten dalam berbagai hal untuk menunjang pekerjaannya didunia kerja.

Menurut Priyatno (1994:266), menyatakan bahwa ada tiga alasan utama mengapa pemberian informasi perlu diselenggarakan. Pertama, membekali individu dengan berbagai masalah yang dihadapi 
berkenaan dengan sekitar, pendidikan, jabatan maupun sosial budaya. Kedua, memmungkinkan individu dapat menentukan arah hidupnya "ke mana dia ingin pergi". Ketiga, setiap individu adalah unik. Keunikan itu akan membawakan pola-pola pengambilan keputusan dan bertindak yang berbeda-beda disesuaikan dengan aspek-aspek kepribadian masing-masing individu.

Berdasarkan penjelasan tersebut pengetahuan tentang informasi dunia kerja membutuhkan berbagai pengetahuan salah satunya jujur dan kompeten dalam dalam berbagai hal yang maka akan membantu menunjang pekerjaan yang dilakukan dengan menghasilkan hasil yang maksimal dalam bekerja membawah individu dapat mengetahui kemana ia menentukan karirnya.

\section{e. Mendalami Pekerjaan yang Lebih Disukai}

Berdasarkan hasil penelitian menunjukan bahwa mahasiswa BK 2018 dengan presentase $43,68 \%$ dengan kategori tinggi dalam mendalami pekerjaan yang lebih disukai. Artinya sebagian besar mahasiswa BK mampu mendalami pekerjaan apa yang lebih disukainya berdasarkan indikator tersebut dapat dilihat salah satunya dengan mengasah bakat yang dimiliki untuk menjadikan pekerjaan pada kemudian hari. Mampu berpikir bahwa bekerja untuk mencari pengalaman bukan hanya mencari uang. Sehingga akan menjadikan pekerjaan hal yang menyenangkan bukan hal yang malah dihindari. Dengan meminta dukungan orang sekitar salah satu contohnya sehingga akan memotivasi diri mendapatkan pekerjaan yang disenangi.

Berbagai informasi karir mencakup informasi tentang kesuksesan kerja seseorang dalam berbagai bidang, macammacam kerja, kondisi aktivitas kerja (aktivitas kerja yang memberikan pelayanan kepada manusia, aktivitas kerja yang menggunakan peralatan atau teknologi, dan aktivitas kerja yang berada diruang terbuka), kompensasi kerja seperti gaji, jaminan kesehatan dan hati tua atau pensiun, syarat pekerjaan yaitu kompetensi yang dimiliki, jenjang pendidikan, pengalaman kerja dan informasi berbagai perguruan tinggi yang terkait dengan jenis pekerjaan (Munandir, 1996: 24).

Berdasarkan penjelasan tersebut mendalami pekerjaan yang disukai akan mampu dilakukan bukan hanya dengan mengasah bakat diri namun juga didukung dengan orang-orang sekitar yang mendukung keputusan yang kita ambil sehingga bekerja bukan hanya mencari uang melainkan juga pengalaman.

\section{f. Realitas dalam Membuat Keputusan Karir}

Berdasarkan hasil penelitian menunjukan bahwa mahasiswa BK 2018 dengan presentase $43,68 \%$ dengan kategori tinggi dalam realitas membuat keputusan karir yang kategori tinggi. Artinya sebagian besar mahasiswa BK sudah memiliki pola pikir yang realistis dalam membuat keputusan karirnya kelak berdasarkan indikator tersebut seperti mencari pengalam dari praktek kerja lapangan dengan bisa melihat gambaran bagaimana dunia kerja itu nantinya. Memilih bekerja keras untuk mendapatkan jabatan yang diinginkan. Menggunakan ijazah pendidikan yang didapatkan untuk mencari pekerjaan nantinya. Berpikir bahwa bekerja keras akan mendapatkan hasil yang maksimal dikemudian hari.

$$
\text { Hasan (2006: }
$$

menjelaskan, kematangan karir identik dengan pengambilan sikap dan kompetensi yang berkaitan dengan pengambilan keputusan karir, yang telah didefinisikan secara normatif dalam hal kesesuaian antara perilaku karir dan perilaku kepribadian pada usia yang telah ditunjukkannya. Melalui perencanaan karir, setiap idividu mengevaluasi kemampuan dan minatnya sendiri, mempertimbangkan kesempatan karir alternatif, menyusun tujuan 
karir, dan merencanakan aktivitas-aktivitas pengembangan praktis. Fokus utama dalam perencanaan karir haruslah sesuai antara tujuan pribadi dan kesempatankesempatan yang secara realistis tersedia.

$$
\text { Berdasarkan penjelasan }
$$

tersebut, realitas dalam membuat keputusan karir dapat dilakukan dengan melihat secara realitas dalam menentukan keputusan karirnya kelak, sehingga dalam bekerja mendapatkan hasil yang diinginkan. Dengan mampu menggunakan ijazah untuk bekerja sesuai dengan kemampuan, bekerja keras untuk mencapai target jabatan yang diinginkan.

\section{KESIMPULAN}

Berdasarkan analisis data dan pembahasan dapat diambil kesimpulan Kematangan Karir Mahasiswa BK STKIP PGRI Sumbar dan Penerapannya dalam Layanan Konseling Karir studi terhadap Mahasiswa BK angkatan 2018. Temuan penelitian ini dapat disimpulkan sebagai berikut:

Secara umum kematangan karir mahasiswa BK 2018 berada pada kategori cukup tinggi yaitu 51,72\% Kematangan Karir Mahasiswa BK STKIP PGRI Sumbar dan Penerapannya dalam Layanan Konseling Karir studi terhadap Mahasiswa BK angkatan 2018. Menggunakan satu variable dan enam indikator yaitu.

(1) keterlibatan dalam aktivitas-aktivitas rencana karir;

(2) adanya keinginan untuk menggali dan mendapatkan informasi karir;

(3) memiliki pengetahuan tentang membuat keputusan yang memadai;

(4) memiliki pengetahuan tentang beberapa informasi pekerjaan dan dunia kerja;

(5) mendalami pekerjaan yang lebih disukai; dan

(6) realistis dalam membuat keputusan karir.

\section{REFERENSI}

Andih, D. C. 2018. Peran Media Sosial
Facebook , Instagram , Youtube )

Dalam Menarik Attractions

Tetempangan Hill is one tourist attraction that is booming and become an idol for. 13(1), 74-80.

Hurlock, Elizabeth B.2002. Psikologi Perkembangan: Suatu Pendekatan Sepanjang Rentang Kehidupan. Erlangga: Jakarta.

Hasan. 2006. Analisis Data Penelitian Dengan Statistic. Jakarta: Bumi Aksara

Lunenburg, F. C. 2010. The Decision Making Process. National Forum Of Education Administration And Supervision Journal Volume 27, No 4, Hal 1-11

Munandir. 1996. Program Bimbingan Dan Konseling Disekolah. Jakarta: Depdikbud

Prayitno. 1994. Dasar-dasar Bimbingan dan Konseling. Jakarta : Rineka Cipta

Salami, Samuel Olayinka.2008. Gender, Identity, Status, And Career Maturity Of Adolescents In Southwest Nigeria. Journal Of Social Science, Ibadan Nigeria University, Volume 16 (1), 3549.

Simamora, H. 2001. Manajemen Sumber Daya Manusia. Yogyakarta: STIE YKPN

Suherman, Uman. 2010. Konseling Karir Sepanjang Rentang Kehidupan, Sekolah Pasca Sarjana Universitas Pendidikan Indonesia

Tekke, Mustafa \& Muhammad A. Ghani.2013. Examining The Level of Career Maturity Among Asian Foreign Students In A Public University:Genderand Academic Achievement.Hope Journal of Research, Volume 1, Issue1, Maret 2013.

Winkel, W.S. \& M.M. Sri Hastuti.2006.Bimbingan dan Konseling di Institusi Pendidikan. Media Abadi: Jakarta.

Zellatifanny, C. M., \& Mudjiyanto, B. 2018. Tipe Penelitian Deskripsi Dalam Ilmu 
Komunikasi. Diakom: Jurnal Media

Dan Komunikasi, 1(2), 83-90. 